\title{
Localization of the accessory pathway in ventricular preexcitation (WPW) by means of combined ECG and VCG recordings
}

\author{
Citation for published version (APA): \\ Nzayinambaho, K., Leclercq, P. A., Waleffe, A., Kulbertus, H., \& Brohet, C. R. (1989). Localization of the \\ accessory pathway in ventricular preexcitation (WPW) by means of combined ECG and VCG recordings. \\ Journal of Electrocardiology, 22 Suppl, 183-188. https://doi.org/10.1016/S0022-0736(07)80121-X
}

DOI:

10.1016/S0022-0736(07)80121-X

Document status and date:

Published: 01/01/1989

\section{Document Version:}

Publisher's PDF, also known as Version of Record (includes final page, issue and volume numbers)

\section{Please check the document version of this publication:}

- A submitted manuscript is the version of the article upon submission and before peer-review. There can be important differences between the submitted version and the official published version of record. People interested in the research are advised to contact the author for the final version of the publication, or visit the DOI to the publisher's website.

- The final author version and the galley proof are versions of the publication after peer review.

- The final published version features the final layout of the paper including the volume, issue and page numbers.

Link to publication

\footnotetext{
General rights

- You may freely distribute the URL identifying the publication in the public portal. follow below link for the End User Agreement:

www.tue.nl/taverne

\section{Take down policy}

If you believe that this document breaches copyright please contact us at:

openaccess@tue.nl

providing details and we will investigate your claim.
}

Copyright and moral rights for the publications made accessible in the public portal are retained by the authors and/or other copyright owners and it is a condition of accessing publications that users recognise and abide by the legal requirements associated with these rights.

- Users may download and print one copy of any publication from the public portal for the purpose of private study or research.

- You may not further distribute the material or use it for any profit-making activity or commercial gain

If the publication is distributed under the terms of Article $25 \mathrm{fa}$ of the Dutch Copyright Act, indicated by the "Taverne" license above, please 


\title{
Localization of the Accessory Pathway in Ventricular Preexcitation (WPW) by Means of Combined ECG and VCG Recordings
}

\author{
K. Nzayinambaho, MD, ${ }^{*} \mathrm{Ph}$. Leclercq, Eng, ${ }^{\dagger} \mathrm{A}$. Waleffe, MD, ${ }^{*}$ \\ H. Kulbertus, $\mathrm{MD}^{*}$ and C. Brohet, $\mathrm{MD}^{\dagger}$
}

The noninvasive localization of the accessory pathway (AP) responsible for ventricular preexcitation is helpful in the initial evaluation of patients with Wolff-Parkinson-White (WPW) syndrome. Recently, two groups of authors independently published new classifications derived from the correlation of 12-lead ECG with electrophysiologic studies. ${ }^{1,2}$ Although these classifications allow a more precise localization of the accessory pathway than the Rosenbaum criteria, ${ }^{3}$ some cases remain difficult to classify. We used the Frank vectorcardiogram (VCG) to increase the accuracy and to simplify classification.

\section{Material and Methods}

The study population consisted of a series of 70 consecutive patients with WPW syndrome, 61 adults and 9 children. In each patient, the ECG was analyzed visually using an $8 \mathrm{X}$ magnifying glass and the VCG was displayed on a VERSATEC printer-plotter after computerized analysis by the LOUVAIN program. ${ }^{4}$ First, the ECG was used to classify each case into one of five groups according to the polarity of the delta wave and of the QRS complex in all 12 leads: group 1, left lateral; group 2; left posteroseptal; group 3, right posterior paraseptal; group 4, right lateral; and group 5, anteroseptal. Then we studied the correlation between the ECG and the VCG in each case. The VCG analysis focused on the mor-

\footnotetext{
* From the Department of Cardiology, University of Liège, Belgium. ${ }^{\dagger}$ From the Department of Cardiology, University of Louvain, Belgium. Reprint requests: C. Brohet, MD, Cliniques Universitaires StLuc, Division of Cardiology, Avenue Hippocrate 10, B 1200 Brussels, Belgium.
}

phology of the delta and QRST loops in the frontal and horizontal planes and on the spatial orientation of the delta initial and of the maximal QRS vectors. Next we derived VCG criteria corresponding to the ECG classification to simplify and categorize the final attribution of individuals in one of the five groups.

\section{Results}

On the basis of the ECG criteria, 54 tracings were classified in groups $1-5$ and 16 tracings remained of undetermined localization. Only one tracing had an anteroseptal localization (group 5). After VCG analysis and reclassification, of the 16 undetermined localizations, 14 could be definitely classified.

Left lateral accessory pathway (group 1) is characterized as follows (Fig. 1). On the ECG, there are negative delta waves in leads I and aVL and a "concordant" pattern of positive delta and QRS from $V_{1}$ or $V_{2}$ to $V_{6}$. On the VCG the delta loop is leftward and inferior in the frontal plane and leftward and anterior (close to the $\mathrm{Z}$ axis) in the horizontal plane, and the QRS loop is in the same direction.

Left posteroseptal accessory pathway (group 2) is classified as follows (Fig. 2). On the ECG there is a negative delta wave in inferior leads II, III, and aVF and a "concordant" pattern of positive delta and QRS from $V_{1}$ and $V_{6}$. On the VCG, there is superior orientation of the delta wave and QRS in the frontal plane and the horizontal plane is as in group 1 (left anterior delta and QRS)

Right posterior paraseptal accessory pathway (group 3) is classified as follows (Fig. 3). On the ECG, 

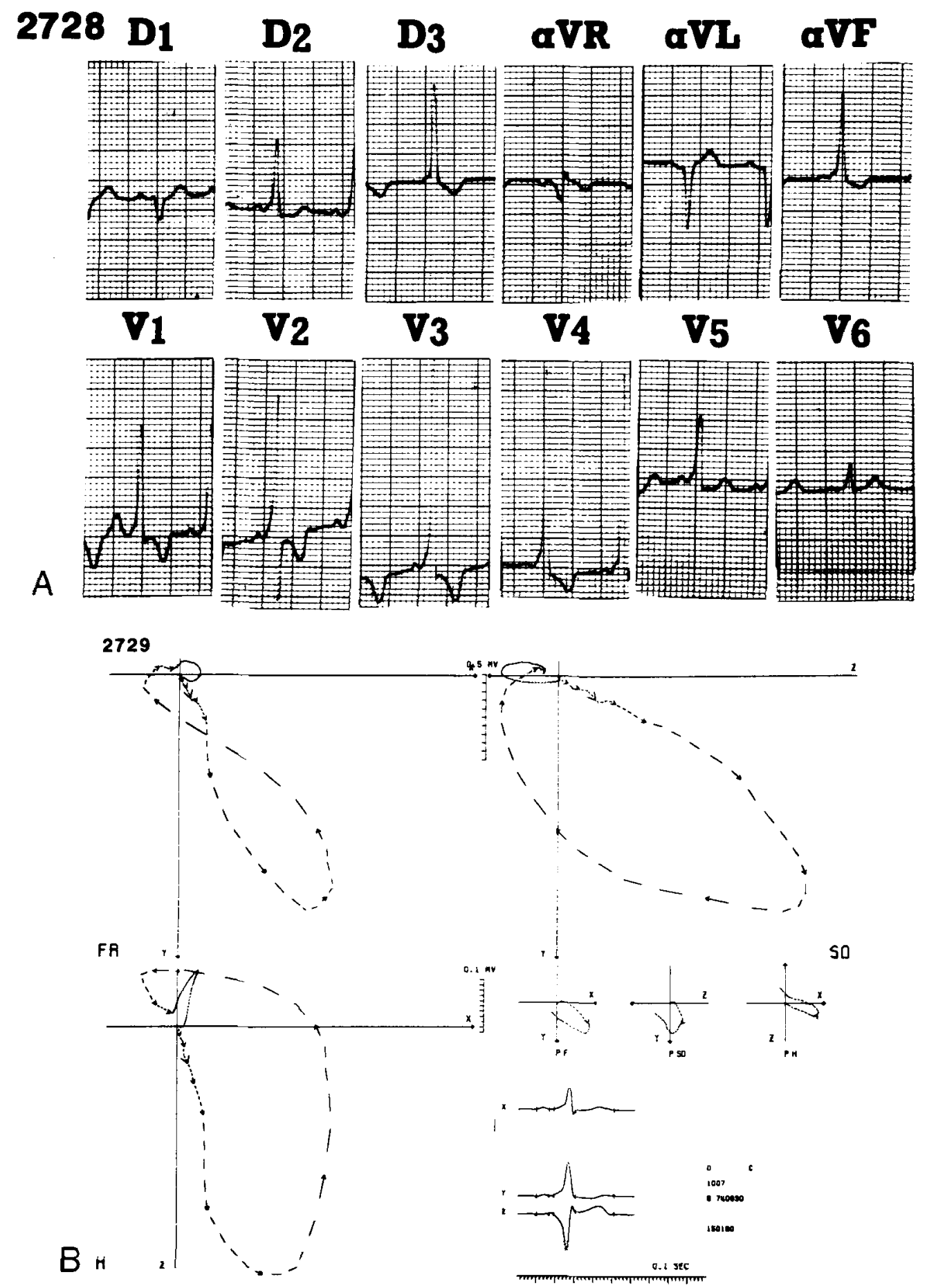

Fig. 1.

there is a negative delta wave in the inferior leads (as in group 2) but a "divergent" aspect in chest leads with $r S$ in $V_{1}$ and $R / S>1$ in $V_{2}-V_{3}$. On the VCG, the pattern is similar to that of group 2 in the frontal plane (superior orientation of delta and QRS), with the exception of less anteriorly oriented delta and QRS in HP (close to the $\mathrm{X}$ axis).

Right lateral accessory pathway (group 4 ) is clas- sified as follows (Fig. 4). On the ECG, there is a negative delta wave only in aVR and there is late transition in chest leads with $R / S<1$ in $V_{1}-V_{3}$. On the VCG, the pattern is the same as group 1 in the frontal plane (inferior and leftward delta and QRS loops). In the horizontal plane there is more posterior orientation of delta and QRS loops (pseudo-LBBB pattern). 

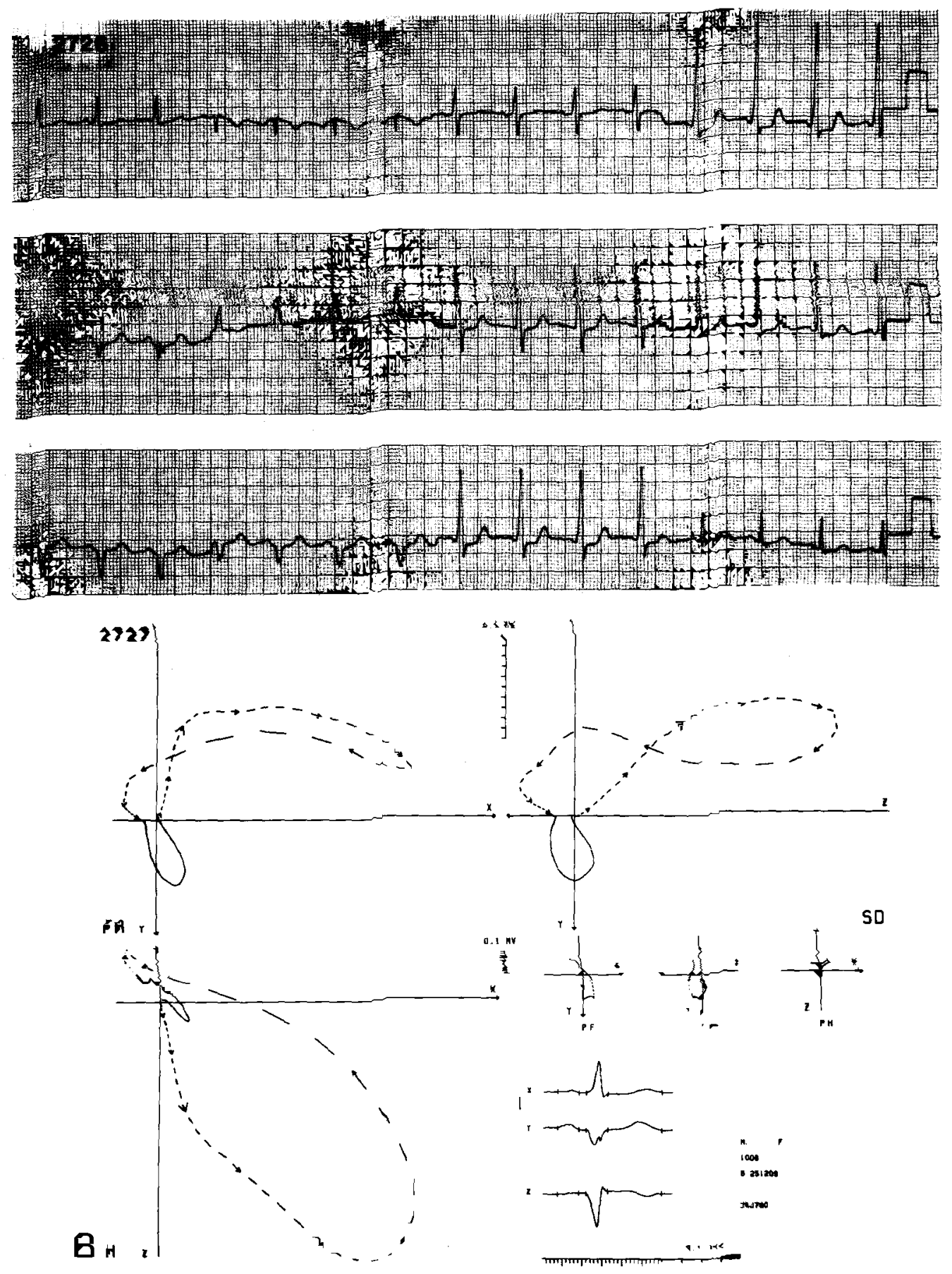

Fis. 2.

\section{Discussion}

The VCG allows a simple localization of the accessory pathway in patients with WPW symdrome. When the delta and QRS loops are inferiorly oriented in the fronial plane, there is a lateral accessory pathway. The lefe lateral accessory pathway (group 1) is characterized by a markedly anterior delta and QRS loops, whereas the right lateral accessory pathway (group 4) shows a much more posterior orientation (pseudo-LBBB patrern). A septal or paraseptal accessory pathway produces a superior orientation of the delta and QRS loops in the frontal plane. The left posteroseptal ascessary pathway (group 2) shows an anteriorly oriented delea and QRS loops (as in group 1), whereas the right posteroseptal accessory pacth- 

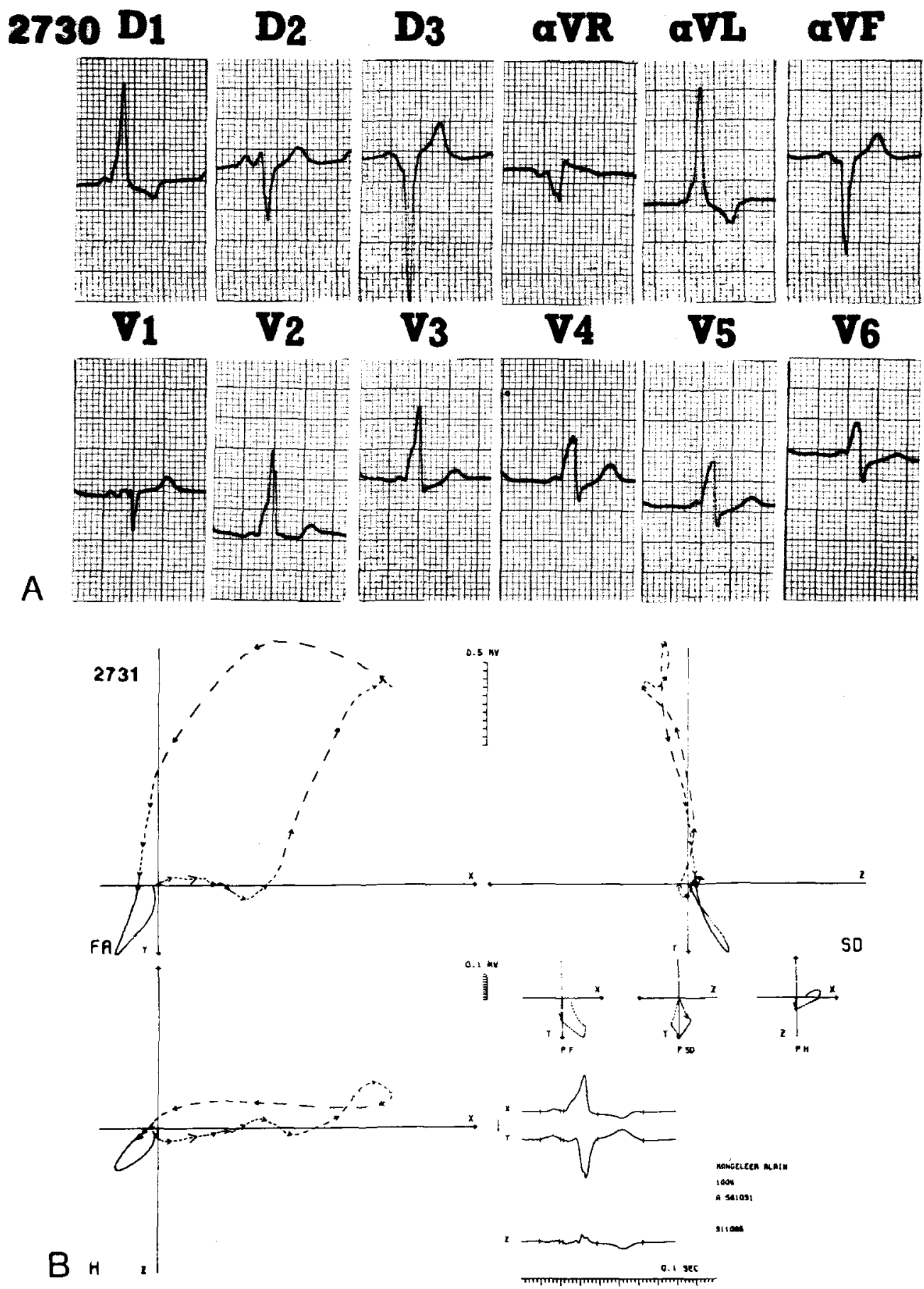

Fig. 3.

way (group 3) shows a more posterior orientation in the horizontal plane.

The combination of these ECG and VCG criteria allows a precise localization of the accessory pathway in most patients with WPW syndrome. After ECG classification of the 70 tracings in this study, $\mathbf{5 4}$ $(77 \%)$ could be classified into the five groups. After VCG reclassification, there were only two remaining cases of undetermined localization. Of course, these criteria must be further validated by correlation with electrophysiologic studies and intraoperative epicardial mapping. The easiest differentiation was between group 1 (left lateral accessory pathway) and group 4 (right lateral accessory pathway), because of the markedly different patterns in the horizontal plane. Sometimes more difficult was the differentia- 

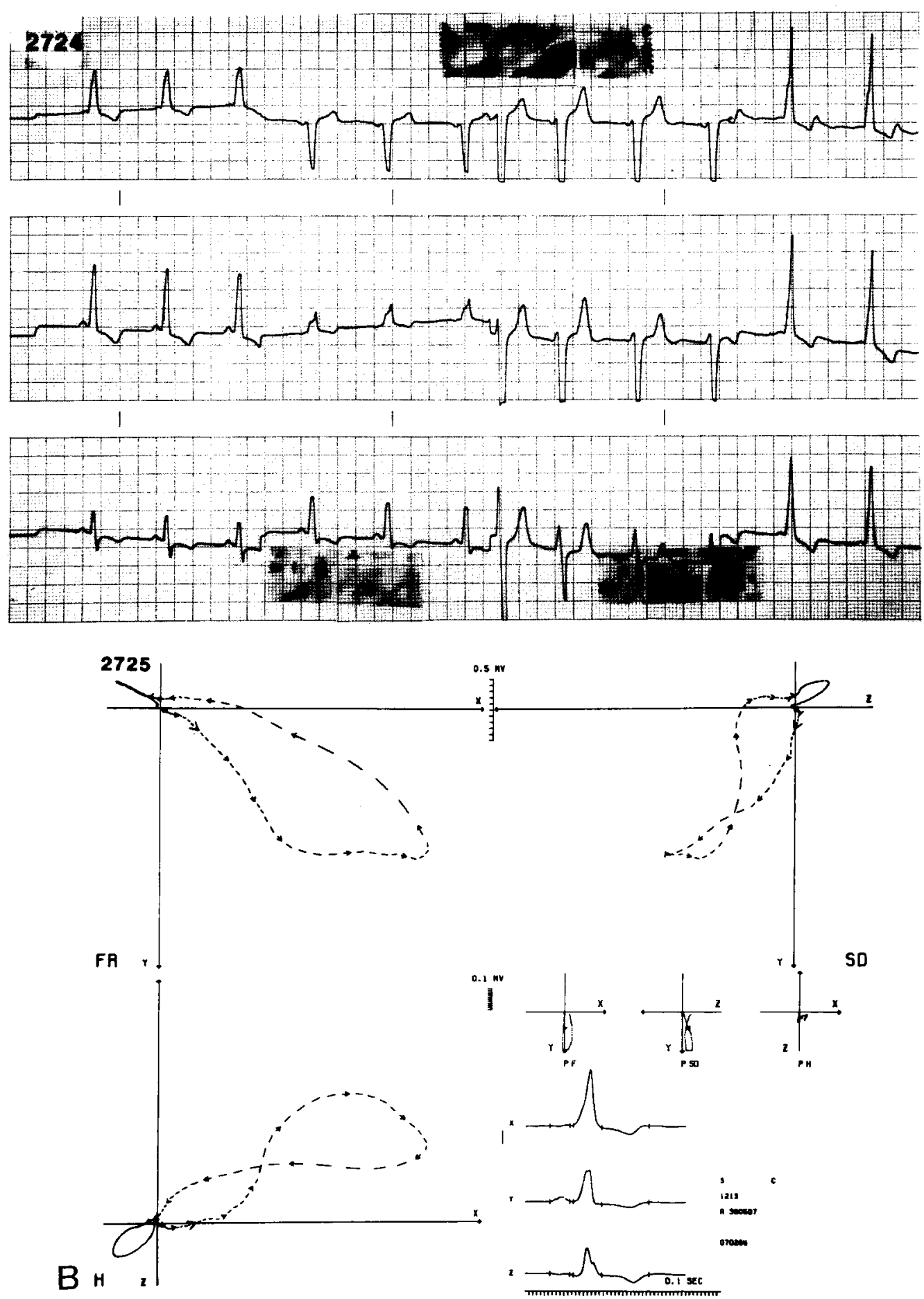

Fig. 4.

tion between group 2 (left posteroseptal) and group 3 (right posteroparaseptal), because of the various degrees of anterior projection of initial delta and QRS in the horizontal plane. In our series, group 2 and group 3 localizations represented the majority. Problems could also arise concerning the localizations in group 4 (right lateral), because it is a rather large zone for the insertion of a bypass tract. Localization in group 5 (anteroseptal) is unusual: in this series, there was only one case.

It is interesting that our results are very close to the criteria proposed by Medvedowsky and Nicolai in their elegant correlation study with electrophysiologic data. ${ }^{5}$ These authors designed VCG criteria from the patterns derived from maximal preexcitation. Their so-called "dynamic" VCG patterns ac- 
tually seem to represent the exaggeration of the patterns we observed on "static" VCGs, during the routine analysis of tracings with various degrees of preexcitation.

\section{References}

L. Lindsay BD, Crossen KJ, Cain ME: Concordance of distinguishing electrocardiographic features during sinus rhythm with the location of accessory pathways in the Wolff-Parkinson-White syndrome. Am J Cardiol 59:1093, 1987
2. Reddy GV, Schamroth L: The localization of bypass tracts in the Wolff-Parkinson-White syndrome from the surface electrocardiogram. Am Heart J 113:984, 1987

3. Rosenbaum FE, Hecht $\mathrm{HH}$, Wilson FN: The potential variations of the thorax and the esophageous in anomalous atrioventricular excitation (Wolff-ParkinsonWhite syndrome). Am Heart J 29:281, 1945

4. Brohet C. Derwael-Barchy C, Fesler R, Brasseur L: Computer-assisted interpretation of orthogonal electrocardiograms and vectorcardiograms by the Louvain system. Acta Cardiol 26(suppl): 19, 1981

5. Medvedowsky JL, Nicolai P, Barnay G et al: Corrélations électrocardiographiques, électrophysiologiques et vectocardiographiques dans le syndrome de WolffParkinson-White. Arch Mal Coeur 71:1000, 1978 